\title{
Endovideosurgery and surgical correction of a genetic bilary circus cyst of children
}

\author{
Rasulbek Aipov ${ }^{1}$, Damir Jenalayev ${ }^{1}$, Bulat Jenalayev ${ }^{2}$, Vladimir Kotlobovsky ${ }^{2}$, \\ Dulat Mustafinov ${ }^{1}$, Aslan Ergaliev², Omar Mamlin'
}

${ }^{1}$ Corporate Fund "University Medical Center" National Research Center for Maternal and Child Health, 1 ${ }^{2}$ West Kazakhstan State Medical Academy Republic of Kazakhstan, Aktobe

\section{ABSTRACT}

Objective. Comparative evaluation of the results of treatment of patients with congenital cysts of the common bile duct, operated with "open" and endovideosurgical methods

Methods. In the treatment of 39 patients, the methods of endovideosurgery (the main group) were used, in the remaining 28 patients (control group) we performed a similar "open" operation. In the postoperative period, all children underwent standard antibiotic therapy with broad-spectrum antibiotics. Within 3 days, all children were given parenteral nutrition, analgesic therapy.

Results. The average indices of "stress hormones" stayed within the limits of normal values before the operation, without significant differences between themselves. Intraoperative indices of "stressful" hormones in both groups significantly exceeded the average values of normal indices. At the same time, a higher degree of endocrine response was noted by us in the group of patients undergoing a traditional operation. This, in all probability, is associated with more traumatic access to the operation object (a wide laparotomy incision, the intersection of a large mass of muscle tissue). Postoperative indices in both groups were lower than intraoperative values, but a more pronounced decrease was seen in the group of patients undergoing laparoscopic surgery.

Conclusion: Presentation of laparoscopic interventions in the surgical correction of cysts in the common bile duct in children causes a lower degree of surgical aggression of the body in the postoperative period in comparison with traditional surgical interventions, which causes a milder period of the postoperative period. Paraposcopic access can be a method of choice for surgical correction of the pathology of external bile ducts in children.

Keywords: endovideosurgery - surgical correction - cysts of the common bile duct - pediatric surgery. Center «Национальный научный центр материнства и детства», Адрес: 010000 Казахстан, г.Астана, пр.Туран, 32. тел: 8(701) 522-12-89, e-mail - damir1972@mail.ru

\section{UDC: 616.36-002.951.21-089-053.2}

\section{J Clin Med Kaz 2017; 3(45 Suppl 3):58-62}

Автор для корреспонденции: Дженалаев Дамир Булатович, д.м.н., руководитель отдела детской Булатович, д.м.н., руководитель отдела детской

\section{ТҰЖЫРЫМДАМА}

БАЛАЛАРҒА АРНАЛҒАН ГЕНЕТИКАЛЫҚ АНЫҚТАЛҒАН ЖАҒДАЙДЫҢ АЯҚТАУЫ ЖӘНЕ ЕРЕКШЕЛІКТЕРІ Аипов Р.Р. ${ }^{1}$, Дженалаев Д.Б. ${ }^{1}$, Дженалаев Б.К. ${ }^{2}$, Котлобовский В.И. ${ }^{2}$, Мустафинов Д.А. ${ }^{1}$, Ергалиев А.Е. ${ }^{2}$, Мамлин О.А.1

"University Medical Center" корпоративтік қорының «Ана мен бала ұлттық ғылыми орталығы»

Мақсаты: «Ашық» және эндовидеохирургиялық әдістермен басқарылатын жалпы өт қабының туа біткен кисталары бар науқастарды емдеу нәтижелерін салыстырмалы бағалау.

Зерттеудің әдістері. 39 пациентті емдеуде эндовидеохирургия (негізгі топ) әдісі пайдаланылды, қалған 28 науқаста (бақылау тобында) біз осындай «ашық» операция жасадық, операциядан кейінгі кезеңде барлық балалар антибиотикамен стандартты антибиотикамен ем алды. 3 күн ішінде барлық балаларға парентеральді тамақтану, анальгетиктерді емдеу берілді.

Нәтижелері. Операциядан бұрын «стресс гормондары» орташа көрсеткіштері қалыпты мәндер шегінде қалды, олар арасында маңызды айырмашылықтар болмады. Екі топтағы «стресстік» гормондардың интроперативті көрсеткіштері қалыпты индекстердің орташа мәндерін айтарлықтай асты. Сонымен қатар, дәстүрлі операциядан өткен науқастар тобында біз эндокриндік жауаптың жоғары дәрежесін атап көрсеттік. Бұл, ең алдымен, операция нысанына (кең лапаротомия кесірінен, бұлшықет тінінің үлкен массасының қиылысуына) 
травматикалық қол жеткізумен байланысты. Екі топтағы операциядан кейінгі көрсеткіштер интроперапиялық мәндерден төмен болғанымен, лапароскопиялық хирургиядан өткен науқастар тобында айтарлықтай айқын төмендеу байқалды.

Қорытынды: Лапароскопиялық араласулардың балалардағы жалпы өт жолындағы кисталардың хирургиялық түзілуіне байланысты операциядан кейінгі кезеңдегі хирургиялық агрессияның анағұрлым төмен дәрежесі, дәстүрлі хирургиялық араласулармен салыстырғанда, операциядан кейінгі кезеңнің жұмсақ кезеңін тудырады.Парапоскопиялық қол жеткізу балалардағы сыртқы өт қабының патологиясын хирургиялық түзету үшін таңдау әдісі болуы мүмкін.

Маңызды сөздер: эндовидеохирургия - хирургиялық коррекция - жасыл протока - балалар хирургиясының кисталары.

\section{РЕЗЮМЕ}

ЭНДОВИДЕОХИРУРГИЯ И ХИРУРГИЧЕСКАЯ КОРРЕКЦИЯ КИСТ ОБЩЕГО ЖЕЛЧНОГО ПРОТОКА У ДЕТЕЙ

Дженалаев Д.Б. ${ }^{1}$ Дженалаев Б.К. ${ }^{2}$, Котлобовский В.И. ${ }^{2}$, Мустафинов Д.А. ${ }^{1}$, Ергалиев А.Е. ${ }^{2}$, Мамлин О.А. ${ }^{1}$

${ }^{1}$ Корпоративный фонд «University Medical Center «Национальный научный центр материнства и детства»1

Западно-Казахстанская государственная медицинская академия, Республика Казахстан, г.Актобе 2

Цель исследования: сравнительная оценка результатов лечения пациентов с врожденными кистами общего желчного протока, оперированных «открытым» и эндовидеохирургическим способами.

Методы. В лечении 39 пациентов были использованы методы эндовидеохирургии (основная группа), у остальных 28 пациентов (контрольная группа) нами была проведена аналогичная «открытая» операция.В послеоперационном периоде всем детям проводилась стандартная антибактериальная терапия антибиотиками широкого спектра действия. В течение 3-х суток всем детям проводилось парентеральное питание, обезболивающая терапия.

Результаты. Перед операцией средние показатели «стрессовых гормонов» пребывали в пределах нормальных значений, не имея достоверных различий между собой. Интраоперационные показатели «стрессовых» гормонов в обеих группах существенно превышали средние величины нормальных показателей. При этом более высокая степень эндокринного ответа была отмечена нами в группе пациентов, которым проводилась традиционная операция. Это, по всей вероятности, связано с более травматичным доступом к объекту операции (широкий лапаротомный разрез, пересечение большого массива мышечной ткани). Послеоперационные показатели в обеих группах были ниже интраоперационных значений, но более выраженное снижение было выражено в группе пациентов, которым проводилась лапароскопическая операция.

Выводы: Выполнение лапароскопических вмешательств при хирургической коррекции кист общего желчного протока у детей вызывает меньшую степень хирургической агрессии организма в послеоперационном периоде по сравнению с традиционными оперативными вмешательствами, что обуславливает более мягкое течение послеоперационного периодалапароскопический доступ может стать методом выбора при хирургической коррекции патологии наружных желчевыводящих путей у детей.

Ключевые слова: эндовидеохирургия - хирургическая коррекция- кисты общего желчного протока- детская хирургия.

\section{Введение}

Одним из наиболее актуальных и сложных вопросов детской хирургии является хирургическая коррекция пороков развития желчевыводящих путей, одним из которых являются кистозные образования общего желчного протока $[1,2,3]$.

В связи с совершенствованием ранее известных и внедрением новых методов диагностики кистозные трансформации желчевыводящих путей стали выявлять гораздо чаще, чем в недавнем прошлом. Одной из причин раннего поступления детей в стационар является онкологическая настороженность врачей поликлинического звена, проявляющаяся в отношении объемных образований любой локализации, в частности, гепатопанкреатодуоденальной зоны.

Еще сравнительно недавно хирургическое лечение кист общего желчного протока у детей включало оперативное вмешательство из верхнесрединного или подреберного лапаротомного доступа с массивной травмой передней брюшной стенки, повреждением нервов, высоким риском развития осложнений в послеоперационном периоде $[4,5]$.

С развитием эндовидеохирургии стало возможным выполнение сложных реконструктивных вмешательств на желчевыводящих путях с использованием методов лапароскопической хирургии. В настоящее время лапароскопия не только конкурирует с традиционными хирургическими вмешательствами, но и превосходит их по ряду параметров, нередко становясь методом выбора в лечении кист общего желчного протока у детей $[6,7,8]$.

Целью данной работы сравнительная оценка результатов лечения пациентов с врожденными кистами общего желчного протока, оперированных «открытым» и эндовидеохирургическим способами.

\section{Материалы и методы}

С 2008 года в отделениях детской хирургии Национального Научного центра материнства и детства и Западно-Казахстанской государственной медицинской академии находилось на лечении 67 пациентов с врожденными кистами общего желчного протока. Возраст пациентов колебался от шести месяцев до 13 лет. У 61 пациента (91\%) отмечались жалобына боли в области правого подреберья, у пятнадцати $(22 \%)$ - явления транзиторной желтухи. У шести пациентов (8,9\%) клинические симптомы отсутствовали. Для уточнения диагноза всем детям проводили ультразвуковое исследование, компьютерную томографию и магнитно-резонансную томографию в режиме холангиографии.

В лечении 39 пациентов нами были использованы методы эндовидеохирургии (основная группа). Этим пациентам производили лапароскопическое иссечение кистозно-измененных желчных ходов с формированием гепатикоэнтероанастомоза по Ру. В первых пяти случаях выполняли лапароскопически ассистированную операцию, при которой один из этапов (формирование межкишечного анастомоза по Ру) выполняли экстракорпорально, через дугообразно расширенный разрез в пупке. В остальных 34 случаях все этапы операции были выполнены полностью лапароскопическим способом. Кистозно-измененный общий печеночный проток пересекали максимально близко $(0,5$ см) к месту слияния правого и левого печеночного протоков

Техника оперативного вмешательства. Для обеспечения лапароскопического доступа использовали 5 троакаров. У детей до в возрасте до трех лет использовали троакары 3,5 мм для инструментов итроакар 5 ммдля телескопа, у детей старше 3 лет с кистозными мальформациями - 5-миллиметровые инструменты. Создавали карбоксиперитонеум 10-12 мм 
рт.ст. При лапароскопических операциях на желчных путях полностью соблюдали принципы аналогичных операций, выполняемых из лапаротомного доступа. На первом этапе операции лапароскопически иссекали все кистозно-измененные наружные желчевыводящие пути (рис.1). Общий желчный проток пересекали максимально близко к двенадцатиперстной кишке и культю ушивали

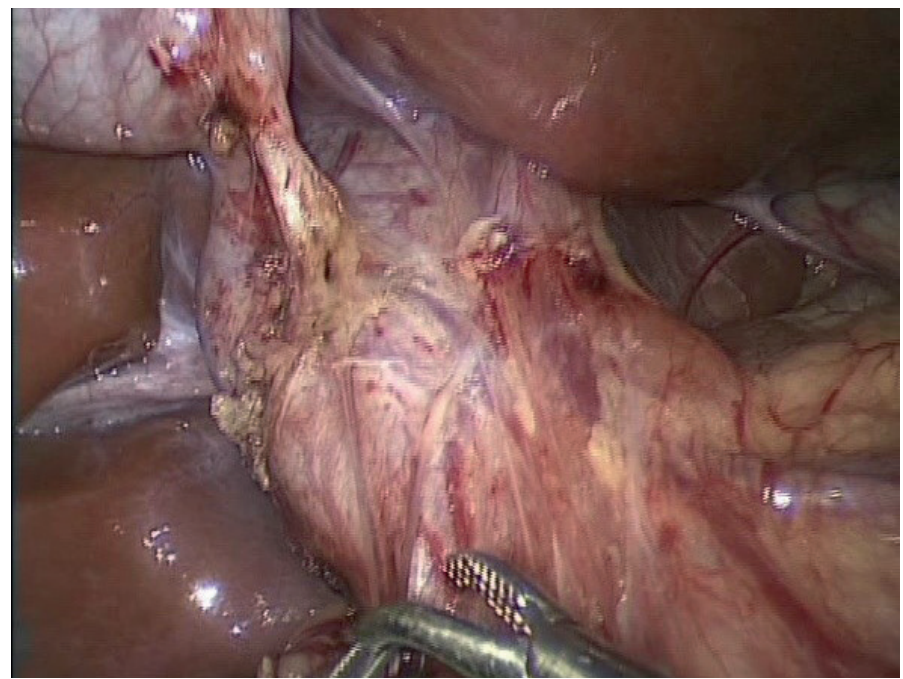

Рисунок 1- Мобилизация кисты общего желчного протока

Как уже было указано второй этап отличался в зависимости от накопления опыта выполнения операций. В первых пяти случаях данный этап операции выполняли экстракорпорально. Для этого отверстие троакара, установленного в пупке, расширяли дугообразно до $2-3$ см. В рану выводили предварительно локализованную первую петлю тощей кишки. Затем формировали межкишечный U-образный анастомоз по Ру. Длина сформированной петли - около 40 см. Сформированную петлю Ру и петли кишечника погружали в брюшную полость. Минилапаротомный разрез ушивали, герметизируя брюшную полость. Экстракорпоральный этап операции заканчивали установкой в брюшную полость троакара для телескопа. В остальных случаях данный этап операции был

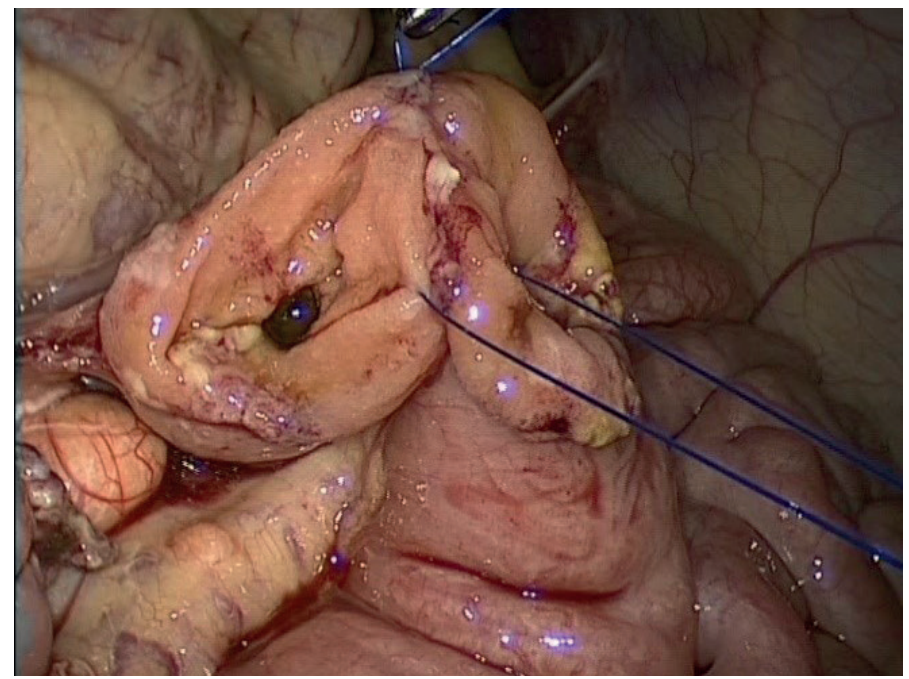

Рисунок 3 - Формирование кишечного анастомоза

У остальных 28 пациентов (контрольная группа) нами была проведена аналогичная «открытая» операция.

В послеоперационном периоде всем детям проводилась стандартная антибактериальная терапия антибиотиками узловым швом (PDS-2 - 4/0). Кистозно-измененный общий печеночный проток пересекали максимально близко к месту слияния правого и левого печеночного протоков (рис.2). Первый этап лапароскопической операции заканчивали визуализацией первой петли тощей кишки.

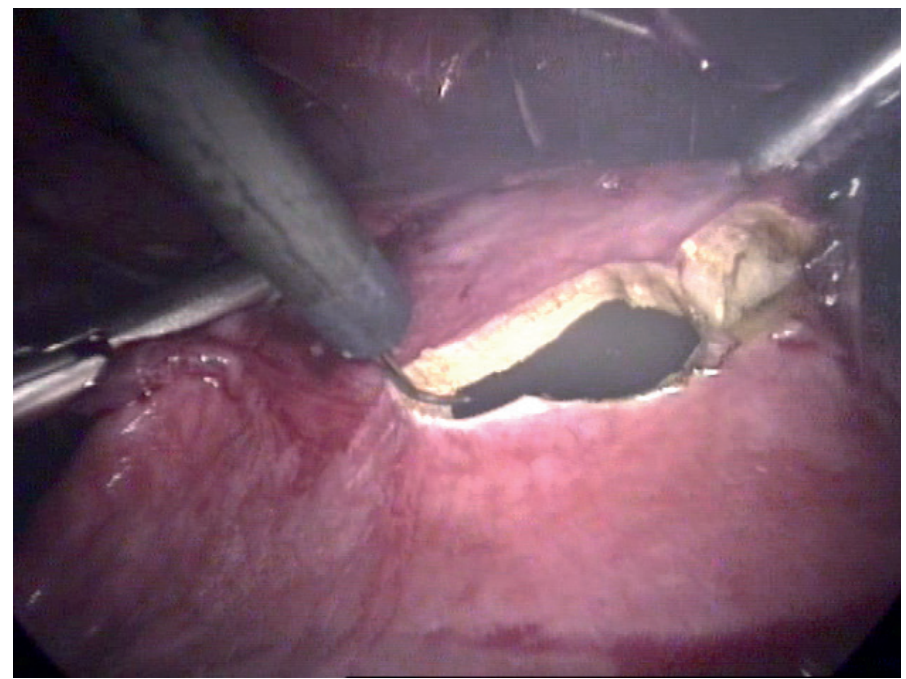

Рисунок 2- Пересечение общего печеночного протока выполнен полностью лапароскопическим способом (рис. 3). Третий этап операции - формирование гепатокоеюноанастомоза проводили лапароскопически (рис. 4). В брыжейке поперечной ободочной кишки формировали окно, через которое петлю Ру проводили в подпеченочное пространство. Кистозно-измененный общий печеночный проток пересекали максимально близко (0,5 cм) к месту слияния правого и левого печеночного протоков. Между культей печеночного протока и петлей кишки накладывали анастомоз по типу конец в бок. При создании анастомоза использовали узловые швы, которые завязывали экстракорпорально - PDS-2-5/0. Окно в брыжейке толстой кишки ушивали. Операция заканчивалась подведением к зоне гепатикоеюноанастомоза дренажной трубки.

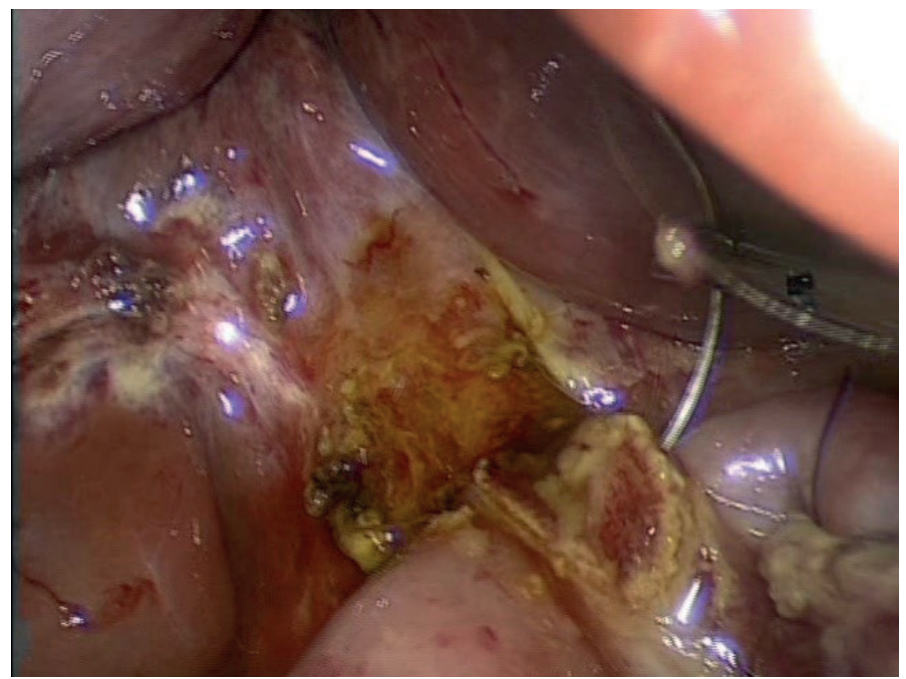

Рисунок 4 - Создание гепатикоеюноанастомоза

широкого спектра действия. В течение 3-х суток всем детям проводилось парентеральное питание, обезболивающая терапия. 


\section{Результаты}

Интра и послеоперационных осложнений в наших наблюдениях не отмечалось.

Для проведения сравнительной оценки постагрессивной реакции организма на лапароскопическую и традиционные виды операций нами было изучено:

- изменение динамики «стрессовых гормонов» (кортизол, пролактин) в ответ на операционную травму;

- изменение вариабельности сердечного ритма (ИН индекс напряжения) в ответ на операционную травму;

- динамика двигательной активности и болевого синдрома в послеоперационном периоде.

Результаты исследования динамики стрессовых гормонов представлены в таблицах 1,2.

Какпоказалирезультатыисследования,передоперацией средние показатели «стрессовых гормонов» пребывали в пределах нормальных значений, не имея достоверных различий между собой. Интраоперационные показатели «стрессовых» гормонов в обеих группах существенно превышали средние величины нормальных показателей. При этом более высокая степень эндокринного ответа была отмечена нами в группе пациентов, которым проводилась традиционная операция. Это, по всей вероятности, связано с более травматичным доступом к объекту операции (широкий лапаротомный разрез, пересечение большого массива мышечной ткани). Послеоперационные показатели в обеих группах были ниже интраоперационных значений, но более выраженное снижение было выражено в группе пациентов, которым проводилась лапароскопическая операция.

Таблица 1 Уровень кортизола у пациентов, оперированных по поводу кисты холедоха (норма 140-600 нмоль/л, $\mathrm{n}-$ количество проведенных исследований)

\begin{tabular}{|l|l|l|l|}
\hline & До операции & $\begin{array}{l}\text { Во время } \\
\text { операции }\end{array}$ & $\begin{array}{l}\text { После } \\
\text { операции }\end{array}$ \\
\hline Основная группа & & & \\
\hline$(\mathrm{n}=39)$ & $331,4 \pm$ & & \\
\hline 77,96 & $686,8 \pm 67,91$ & $419,7 \pm 67,84$ & \\
\hline Контрольная группа (n=28) & $335,2 \pm 78,86$ & $648,5 \pm 69,31$ & $\begin{array}{l}514,6 \pm \\
57,01\end{array}$ \\
\hline
\end{tabular}

Таблица 2 Уровень пролактина у пациентов, оперированных по поводу кисты холедоха (норма 57-600 мМе/мл, $\mathrm{n}$ - количество проведенных исследований)

\begin{tabular}{|l|l|l|l|}
\hline & До операции & $\begin{array}{l}\text { Во время } \\
\text { операции }\end{array}$ & $\begin{array}{l}\text { После } \\
\text { операции }\end{array}$ \\
\hline Основная группа & & & \\
\hline$(\mathrm{n}=39)$ & $253,4 \pm$ & & \\
\hline 63,19 & $2554 \pm 639,7$ & $413,6 \pm 119,7$ & \\
\hline Контрольная группа (n=28) & $262,4 \pm 78,16$ & $2498 \pm 711,3$ & $997 \pm 299,5$ \\
\hline
\end{tabular}

Результаты уровня индекса напряжения (ИН) в анализируемых группах представлены в таблице 3 .

Таблица 3 Динамика индекса напряжения (ИН) при различных методах оперативной коррекции кисты холедоха (n количество проведенных исследований)

\begin{tabular}{|c|c|c|c|c|}
\hline $\begin{array}{l}\text { Методы } \\
\text { операции }\end{array}$ & До операции & Во время операции & $\begin{array}{l}\text { Через } 10 \text { минут после } \\
\text { операции }\end{array}$ & $\begin{array}{l}\text { Через } 24 \text { часа после } \\
\text { операции }\end{array}$ \\
\hline Лапароскопическая оперпация (n=39) & $104,9 \pm$ & & & \\
\hline 14,57 & $172,9 \pm 19,76$ & & & \\
\hline $154,7 \pm 15,66$ & $127,0 \pm 17,11$ & & & \\
\hline Традиционная операция (n=28) & $107,9 \pm 13,55$ & $194,5 \pm 16,86$ & & \\
\hline $198,6 \pm 21,16$ & $153,0 \pm 17,03$ & & & \\
\hline$P$ & $0.289^{* *}$ & $0,000^{*}$ & $0.000^{*}$ & $0.000^{*}$ \\
\hline
\end{tabular}

Из приведенных в таблице данных следует, что:

- перед операцией уровень индекса напряжения в обеих подгруппах находился в пределах нормы без достоверно значимых различий между подгруппами;

- при равных стартовых условиях, интраоперационный уровень ИН был несколько выше у пациентов, которым выполнялись традиционные оперативные вмешательства;

- непосредственно после операции уровень ИН в контрольной группе оставался высоким, в то время как в основной группе отмечалось достоверное снижение ИН;

- через сутки после операции в обоих группах отмечалось снижение показателей ИН, более выраженное в группе пациентов, подвергнувшихся лапароскопическим оперативным вмешательствам.

Анализируя динамику двигательной активности пациентов в послеоперационном периоде, можно отметить, что после лапароскопической операции у $10 \%$ больных болевой синдром купируется к концу первых суток с момента операции, у 40\% больных - к 36 часам послеоперационного периода, у 90\% больных - к концу 2-суток от момента операции, а к концу 3-х суток болевой сидром купировался у $100 \%$ пациентов, перенесших лапароскопическую операцию.

Несколько иная картина наблюдалась у пациентов, перенесших традиционную операцию. После «открытой» операции болевой синдром сохранялся в течение 36 часов у всех пациентов, к концу 2-х суток он купировался только у $20 \%$ пациентов, через 72 часа после операции - у 60\%, а полное отсутствие болевого синдрома в контрольной группе мы отмечали лишь к концу 4-х суток-началу 5-х суток.

Такая же динамика отмечалась и при анализе двигательной активности больных в сравниваемых группах в послеоперационном периоде.

Анализ показал, что более половины пациентов основной группы начинают ходить к концу 2-х суток, а через 72 часа после операции самостоятельно ходили $100 \%$ 
пациентов. У пациентов группы сравнения двигательная активность была более замедленной, они труднее активизировались, с «неохотой» начинали ходить только к началу 4-х суток после операции.

\section{Обсуждение}

Анализ сравнительной оценки постагрессивной реакции организма на лапароскопическую и традиционные виды операций показал, что лапароскопические операции являются менее инвазивным, менее травматичным оперативным вмешательством, которому свойственно более благоприятное течение послеоперационного периода.

Меньшая травматичность уменьшает применение анальгетиков. Так, при эндоскопическом лечении кисты общего желчного протока наркотические анальгетики применялись лишь в течение 12-18 часов послеоперационного периода, а в дальнейшем применяли ненаркотические анальгетики в течение 1,5-2 суток, при традиционных методах оперативного лечения применялись наркотические анальгетики (промедол) в течение полутора двух послеоперационного периода.

\section{Выводы}

Выполнение лапароскопических вмешательств при хирургической коррекции кист общего желчного протока у детей вызывает меньшую степень хирургической агрессии организма в послеоперационном периоде по сравнению с традиционными оперативными вмешательствами, что обуславливает более мягкое течение послеоперационного периода.

Анализируя наш опыт использования лапароскопии в хирургической коррекции кист общего желчного протока, можно отметить, что лапароскопический доступ может стать методом выбора при хирургической коррекции патологии наружных желчевыводящих путей у детей.

\section{Литература}

1. Saing H, Han H, Chan KL, Lan W, Cheng W, Tam PK. Early and late results of excision of choledochal cysts. Journal of Pediatric Surgery 1997; 32(11): 1563-6.

2. She WH, Chang HY, Lan LCL, Won KKY, Saing H, Tam PKH. Management of choledochal cyst: 30 years of experience and results in a single center. Journal of Pediatric Surgery 2009; 44:2307-2311.

3. B.H.Lee, Sh.Hirose, B.Bratton, D.Farmer. Initial experience with complex laparoscopic biliarysurgery in children: biliary atresia and choledochal cyst. Journal of Pediatric Surgery 2004; 39: 804-807.

4. Le DM, Woo RK, Sylvester K, Krummel, Albanese CT. Laparoscopic resection of type 1 choledochal cysts in pediatric patients. Surg Ebdosc 2006; 20: 249-51.

5. Ahn SM, Jun JY, Lee WJ, Han SJ, Choi SH, Hwang EH. Laparoscopic total intracorporeal correction of choledochal cyst in pediatric population. Journal Laparoendos Adv Surg Tech A 2009; 19(5): 683-86.

6. LimNT, Dung le A, Son TN. Laparoscopic complete cyst excision and hepaticoduodenostomy for choledochal cyst: early results in 74 cases. Journal Laparoendos Adv Surg Tech A 2009 19(1): S87-90.

7. Ruiz C.Hierro. Laparoscopic repair for choledochal cyst in children: current status. World Journal of laparoscopic surgery. 2012, 5(2): 76-79.

8. Nguyen Thanh L. Hien PD, Dung le A, Son TN. Laparoscopic repair for choledochal cyst: lessons learned from 190 cases. Journal of Pediatric Surgery 2010; 45(3): 540-4. 